Пархоменко-Куцевіл Оксана Ігорівна доктор наук 3 державного управління, професор, завідувач кафедри публічного управління та адміністрування Переяслав-Хмельницького державного педагогічного університету імені Г. Скоровороди, вул. Сухомлинського, 30, м. Переяслав, 08400, тел.: (050) 922-15-35, e-mail: pkoi@ukr.net, https://orcid.org/0000-00020758-346X

\title{
ІННОВАЦІЙНІ ПІДХОДИ ДО ДЕІНСТИТУЦІАЛІЗАЦІЇ ЗАКЛАДІВ РОЗВИТКУ ТА ВИХОВАННЯ ДІТЕЙ, ЯКІ ЗАЛИШИЛИСЯ БЕЗ ПІКЛУВАННЯ БАТЬКІВ
}

Анотація. У статті аналізуються сучасні проблеми деінституціалізації закладів розвитку та виховання дітей, які залишилися без піклування батьків, визначаються причини таких проблем. Основною проблемою у формуванні якісного кадрового, інтелектуального, творчого капіталу України $є$ виховання та розвиток особистості дітей та молоді. Саме оновлення такого капіталу $\epsilon$ засадами розвитку та процвітання держави. Автором проаналізований досвід формування інституцій для дітей, які залишилися без піклування батьків, у Японії та США. Зазначено, що до інноваційних форм піклування та розвитку дітей, які залишилися без піклування батьків, належать: патронатні вихователі, прийомні професійно підготовлені сім'ї, фостерні сім'ї. Обгрунтована необхідність запровадження інноваційних форм піклування та виховання дітей, які залишилися без піклування батьків. Проведений аналіз дає підстави визначити наступні форми влаштування дітей, які залишилися без піклування батьків: по-перше, професійні прийомні сім'ї. Для цього потрібно заснувати спеціальні курси для навчання прийомних батьків. Окремо передбачити порядок їх підвищення кваліфікації, оволодіння новими методами виховання; по-друге, запровадження діяльності патронатних вихователів. В умовах децентралізації надання об'єднаним територіальним громадам самостійно вирішувати питання запровадження діяльності будинки сімейного типу, прийомних сімей, фінансування зазначених закладів. Окремо потребує питання встановлення стандартів надання адміністративних послуг дітям прийомними сім'ями, будинками сімейного типу. Також потребує прийняття рішення щодо ліцензування прийомних сімей як професійного комерційного виду надання адміністративних послуг для дітей, які залишилися без піклування дітей.

Ключові слова: реформування публічного управління, інституційні установи для дітей, діти, які залишилися без батьківського піклування, державна підтримка інституцій для дітей, інноваційні форми догляду та виховання дітей. 
Parkhomenko-Kutsevil Oksana Ihorivna Doctor of State Administration, Professor, Head of the Department of Public Administration and Administration of Pereyaslav-Khmelnytsky State Pedagogical University named after G. Skorovoroda, Sukhomlinskoho St, 30, Pereyaslav, 08400, tel.: (050) 922-15-35, email: pkoi@ukr.net, https://orcid.org/0000-0002-0758-346X.

\title{
INNOVATIVE APPROACHES TO DEINSTITUTIONALIZATION OF DEVELOPMENT AND EDUCATION INSTITUTIONS OF CHILDREN LEFT WITHOUT CARE OF PARENTS
}

\begin{abstract}
The article analyzed the current problems of deinstitutionalization of institutions for the development and upbringing of children left without parental care, identifies the causes of such problems. The main problem in the formation of high-quality human, intellectual, creative capital of Ukraine is the education and personal development of children and youth. It is the renewal of such capital that is the basis for the development and prosperity of the state. The author analyzed the experience of forming institutions for children left without parental care in Japan and the United States. The article stated that innovative forms of care and development of children left without parental care include: foster carers, foster families, foster families. The author substantiated the need to introduce innovative forms of care and upbringing of children left without parental care. The analysis gives grounds to determine the following forms of placement of children left without parental care: first, professional foster families. To do this, you need to establish special courses for foster parents. Separately provide for the procedure for their training, mastery of new methods of education; secondly, the introduction of foster carers. In the conditions of decentralization, the united territorial communities should be able to independently decide on the implementation of family-type houses, foster families, and the financing of these institutions. The issue of setting standards for the provision of administrative services to children in foster families and family-type homes needs to be addressed separately. It also requires a decision on the licensing of foster families as a professional commercial type of administrative services for children left without child care.
\end{abstract}

Keywords: public administration reform, institutional institutions for children, children left without parental care, state support of institutions for children, innovative forms of care and upbringing of children.

Постановка проблеми. Основною проблемою у формуванні якісного кадрового, інтелектуального, творчого капіталу України $є$ виховання та розвиток особистості дітей та молоді. Саме оновлення такого капіталу $\epsilon$ засадами розвитку та процвітання держави. Однак, на сьогодні відчуваються проблеми відтоку кадрів та молоді з країни, внаслідок соціально-економічної кризи, крім того, більшість дітей перебуваються без піклування батьків, розвивається так зване соціальне сирітства, а також існує проблема неякісного виховання та соціалізації дітей, які залишилися без піклування 
батьків.

Кабінет Міністрів України 9 серпня 2017 року затвердив Національну стратегію реформування системи інституційного догляду та виховання дітей на 2017-2026 роки та визначив етапи розвитку за зазначеного реформування [1].

Разом 3 тим, даний нормативно-правовий документ не визначає дієвих механізмів реформування системи інституційного догляду та виховання дітей, а також не зазначає про інноваційні форми виховання та соціалізації дітей, які залишилися без батьківського піклування.

На сьогодні виникла об'єктивна необхідність у формуванні інноваційних форм виховання та соціалізації дітей, надання нашому молодому поколінню всіх навичок та можливостей для подальшої розбудови української держави, навчити їх жити та розвиватися в мінливих та економічно-несприятливих умовах, захищати свої права, пишатися Батьківщиною та нести позитивні зміни у суспільство.

Аналіз останніх досліджень і публікацій. Проблеми виховання та соціалізації дітей, які опинилися в важких життєвих ситуаціях, без піклування батьків, функціонування інституція, які опікуються дітьмисиротами, дітьми 3 особливими потребами, аналізують багато вчених: психологів, соціологів, юристів, економістів, фахівців 3 державного управління. Так, аналіз інституційного догляду та виховання дітей, які залишилися без батьківського піклування, дітей-сиріт, дітей 3 особливими потребами тощо аналізують, зокрема: Т.Бавол, О.Бурлака, Я.Бордіян, Т.Івлева, Ю.Кахіан, М.Кравченко, Л.Кривачук, О.Крестовська, О.Мордань, В.Покась, О.Прокопенко, В.Резнік, О.Темченко, А.Толкачова, Ю.Харченко, Т.Харук, М.Черепань, I. Ярмолинська та ін.

Разом 3 тим, вістуні системні дослідження проблеми запровадження аналіз інноваційних форм реформування закладів розвитку та виховання дітей, які залишилися без піклування батьків, особливо 3 урахуванням сучасних глобалізаційних та інформаційних викликів.

Метою статті $є$ системний аналіз інноваційних форм реформування закладів розвитку та виховання дітей, які залишилися без піклування батьків.

Виклад основного матеріалу. На сьогодні в Україні виникла проблема пошук та впровадження інноваційних методів виховання та соціалізації дітей, які залишилися без опіку батьків. Інтернатні установи для дітей в Україні, на жаль, лише шкодять дітям, не дають ім. важливих соціальних та комунікативних навичок для подальшого існування у суспільстві, часто такі діти не мають звичайних побутових навичок, а також не вміють будувати

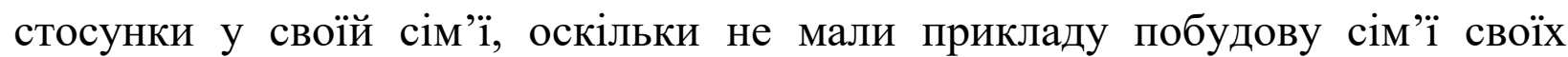
батьків.

Тому, в Україні здійснюється поетапна реформа розбудови інтернатних закладів для дітей з метою їх ефективності.

У зв'язку з цим, проаналізуємо досвід іноземних країни 3 метою імплементації досвіду цих країн для українського законодавства. 
Так, в Японії за останні два десятиліття середня тривалість перебування в дитячих будинках стає більш тривалою і в середньому становить майже 5 років [2].

Останнім часом в Японії зросла кількість дітей, чиї батьки були офіційно позбавлені батьківських прав за недотримання своїх батьківських обов'язків. У зв'язку 3 переповненням соціальних установ японське Міністерство праці, соціального захисту та охорони здоров'я кардинально переглянув існуючу систему опіки дітей.

Відповідно до Постанови від 2002 р. прийомні батьки поділяються на чотири категорії: звичайні прийомні батьки, родичі-опікуни, короткострокові прийомні батьки, спеціалізовані прийомні батьки [2].

Поняття «спеціалізовані прийомні батьки» вперше було введено в 2002 році і має на увазі прийомних батьків, які беруть під опіку дітей, які більше років були травмовані внаслідок неналежного догляду та виховання, насильства, недотримання батьками своїх обов'язків. Спеціалізовані прийомні батьки проходять попереднє навчання за особливою програмою. До них висуваються додаткові, більш серйозні вимоги, зокрема:

1) офіційний дозвіл на опіку і як мінімум 3-річний досвід виховання прийомних дітей;

2) мінімум 3-річний досвід роботи в службах соціального забезпечення дітей [3].

Виконувана робота повинна бути аналогічна вихованню прийомних дітей, про що необхідно надати довідку. До роботи по вихованню прийомних дітей в Японії прирівнюються наступні види діяльності: робота в центрах денного перебування, дитячих будинках, будинках дитини та інших дитячих соціальних установах [2].

Тобто запровадження професійних прийомних сімей $є$ важливою альтернативною проживання та соціалізації дітей, особливо, якщо це буде здійснюватися в межах громади.

Необхідно відзначити, що в Японії держава не тільки оплачує працю прийомних батьків, але і компенсує всі постійні і короткочасні витрати на виховання та навчання дитини (сума варіюється в залежності від віку дитини), догляд за ним, подорожі, організацію дитячого відпочинку. Витрати на медичну допомогу, харчування дітей в школі і факультативні заняття за інтересами відшкодовуються повністю [3].

На нашу думку, запровадження такої альтернативної форми перебування дітей, як оплачувана прийомна сім'я $\epsilon$ важливим аспектом реформування закладів розвитку та виховання дітей, які залишилися без піклування батьків. Крім того, виховання дітей в прийомній сім’і надає можливість якісно соціалізувати дитину, надає їй важливі побутові знання та навички, а також формує позитивне сприйняття дитиною сім’ї, важливих ролей чоловіка та

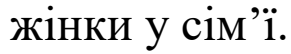

У Сполучених Штатах Америки діє Закон про усиновлення та безпеку сімей від 1997 р. (Adoption and Safe Families Act), а також величезна кількість нормативно-правових актів штатів. Наприклад, найбільш типовими актами $€$ 
Білль про права фостерних батьків (Foster Parent's Bill of Rights), Білль про права дітей, переданих на фостерної виховання (Foster Children's Bill of Rights), які надають певні привілеї, переважні права і обов'язки учасників фостерного договору в особі батьків, держави і дітей. До них відносяться: отримання повідомлень про плани державних органів, які зачіпають інтереси дитини, отримання всій біографічної та медичної інформації про дитину до або під час розміщення, першочергове право фостерних вихователів на усиновлення, коли дитина стає доступним для даної процедури, обов'язок ставитися 3 гідністю і повагою до дитини, відмовляти вихователям в розміщенні дитини в певній сім'ї або вилучати його без здійснення санкцій 3 боку держави, кваліфікована підготовка та постійна підтримка батьків тощо [4].

Федеральне законодавство дає великі повноваження штатам розробляти і здійснювати ліцензування та фінансову підтримку сім'ям, що беруть на виховання дітей, які залишилися без піклування батьків. Кожен штат має свою власну систему ліцензійних стандартів і процедур щодо вирішення проблеми сирітства. Тільки 15 штатів (Алабама, Канзас, Колорадо, Юта, Техас, Флорида та ін.) висувають до родичам ті ж вимоги, що і до прийомних батьків, які не перебувають 3 дитиною в родинних стосунках. У 23 штатах (Теннесі, Нью-Йорк, Верджінія, Каліфорнія і ін.) соціальні служби роблять деякі послаблення (в більшості випадків при проходженні навчання) для родичів дитини. У 20 штатах (Меріленд, Нью-Джерсі, Міссурі і ін.) існує окрема процедура поміщення дитини в сім'ї родичів, що відрізняється від такої для професійних прийомних батьків (що мають ліцензію для заняття даним видом діяльності) [5].

Крім того, деякі штати вводять додаткові вимоги до родичів, що беруть дітей на виховання в сім'ю. Так, в штаті Міссурі дідусь або бабуся, що піклуються про дитину, мають право на отримання допомоги як прийомні батьки, на відміну від інших родичів, які можуть розраховувати на таку виплату тільки в тому випадку, якщо біологічні батьки дитини потрапляють в категорію сімей з низьким матеріальним достатком. В іншому випадку виплата на дитину здійснюється 3 державних фондів соціального захисту, сума якої значно нижче [6].

У Сполучених Штатах Америки питанням фостерингу спільно займаються органи держави $\mathrm{i}$ некомерційні організації. Будь-який патронатний вихователь повинен мати державну ліцензію на здійснення діяльності по вихованню дитини, яка видається від імені Департаменту соціальних служб або Департаменту у справах дітей та сім'ї, затвердженого переліку державних і приватних установ даного штату. Після докладної перевірки кандидатів і проходження навчання (в середньому від 10 до 30 годин) ліцензована сім'я стає фостерними вихователями.

Величезну підтримку державі та громадянам в питаннях фостерингу надає некомерційна організація «Національна асоціація фостерних батьків» (National Foster Parent Association). Вона надає підтримку фостерним вихователям, допомогу по взаємодії з державними структурами, здійснює 
професійну підготовку осіб, які бажають взяти на виховання дитину, усуває правову неграмотність населення щодо патронату в США, а також приймає пожертвування на цілі розвитку і підвищення ефективності фостерингу [4].

На нашу думку, потрібно ліквідувати інтернатні установи та запровадити діяльність замість них будинки сімейного типу, професійних вихователів, фостерні сім’ї, прийомні сім’ї.

Проведений аналіз дає підстави визначити наступні форми влаштування дітей, які залишилися без піклування батьків:

1) професійні прийомні сім’ї. Для цього потрібно заснувати спеціальні курси для навчання прийомних батьків. Окремо передбачити порядок їх підвищення кваліфікації, оволодіння новими методами виховання.

2) Запровадження діяльності патронатних вихователів, які можуть на професійній основні надавати дітям, які залишилися без піклування батьків, адміністративні послуги, послуги з соціалізації, виховання та розвитку.

Крім того, потребує вирішення питання організації проживання тимчасових прийомних сімей 3 дітьми, які залишилися без піклування батьків. Визначення фінансування таких сімей, формування сприятливого середовища та влаштування дітей у звичайні загальноосвітні школи.

В умовах децентралізації потребує вирішення питання надання об’єднаним територіальним громадам самостійно вирішувати проблеми запровадження діяльності будинки сімейного типу, прийомних сімей, фінансування зазначених закладів. Окремо потребує питання встановлення стандартів надання адміністративних послуг дітям прийомними сім'ями, будинками сімейного типу.

Також потребує прийняття рішення щодо ліцензування прийомних сімей як професійного комерційного виду надання адміністративних послуг для дітей, які залишилися без піклування дітей.

Висновки. Проведений аналіз надав можливість зазначити, що сучасна система інтернатних закладів не забезпечують можливість всебічного розвитку дитини, не дає важливих побутових та комунікаційних навичок, часто наносить шкоду дитині. Обгрунтована необхідність запровадження інноваційних форм піклування та виховання дітей, які залишилися без піклування батьків.

\section{Лimepamypa:}

1. Про Національну стратегію реформування системи інституційного догляду та виховання дітей на 2017-2026 роки та план заходів з реалізації іiі I етапу: розпорядження Кабінету Міністрів України від 9 серпня 2017 p. № 526-p. URL: https://zakon.rada.gov.ua/laws/show/526-2017-\%D1\%80\#n23

2. Савенко О.Е. Формы устройства детей, оставшихся без попечения родителей, в зарубежных странах. Вестник Университета имени О. Е. Кутафина. 2015. №2. URL: https://cyberleninka.ru/article/n/formy-ustroystva-detey-ostavshihsya-bez-popecheniyaroditeley-v-zarubezhnyh-stranah. 
3. Гайсина Г. И. Семейное устройство детей-сирот и детей, оставшихся без попечения родителей: российский и зарубежный опыт. 2013. URL: http://www.rfh.ru/downloads/Books/134693008. pdf

4. Бессчетнова О. В. Фостерная семья как способ устройства детей, оставшихся без попечения родителей, в Соединенных штатах Америки. Вестник ТГПУ. 2009. №5. URL: https://cyberleninka.ru/article/n/fosternaya-semya-kak-sposob-ustroystva-detey-ostavshihsyabez-popecheniya-roditeley-v-soedinennyh-shtatah-ameriki.

5. Jantz A., Green R., Bess R., Andrews C., Russell V. The Continuing Evolution of State Kinship Care Policies. Washington, D. C.: The Urban Institute, 2002.

6. Geen R. Kinship Care: Making the Most of a Valuable Resource. Washington, DC: Urban Institute Press, 2003.

\section{References:}

1. Pro Natsionalnu stratehiiu reformuvannia systemy instytutsiinoho dohliadu ta vykhovannia ditei na 2017-2026 roky ta plan zakhodiv z realizatsii yii I etapu: rozporiadzhennia Kabinetu Ministriv Ukrainy vid 9 serpnia 2017 r. № 526-r. [On the National Strategy for Reforming the System of Institutional Care and Upbringing of Children for 2017-2026 and the Action Plan for the Implementation of its First Stage: Order of the Cabinet of Ministers of Ukraine of August 9, 2017 № 526-r.] Retrieved from https://zakon.rada.gov.ua/laws/show/5262017-\%D1\%80\#n23 [in Ukrainian].

2. Savenko, O.E. (2015). Formy ustrojstva detej, ostavshihsja bez popechenija roditelej, v zarubezhnyh stranah [Forms of placement of children left without parental care in foreign countries]. Vestnik Universiteta imeni O. E. Kutafina - Journal of the OE Kutafin University. (2). Retrieved from https://cyberleninka.ru/article/n/formy-ustroystva-detey-ostavshihsya-bezpopecheniya-roditeley-v-zarubezhnyh-stranah. [in Russian]

3. Gajsina, G. I. (2013) Semejnoe ustrojstvo detej-sirot i detej, ostavshihsja bez popechenija roditelej: rossijskij i zarubezhnyj opyt [Family structure of orphans and children left without parental care: Russian and foreign experience]. Retrieved from http://www.rfh.ru/downloads/Books/134693008. pdf [in Russian]

4. Besschetnova, O. V. (2009). Fosternaja sem'ja kak sposob ustrojstva detej, ostavshihsja bez popechenija roditelej, $\mathrm{v}$ Soedinennyh shtatah Ameriki [Foster family as a way of arranging children left without parental care in the United States of America]. Vestnik TGPU - Journal of TSPU. (5). Retrieved from https://cyberleninka.ru/article/n/fosternaya-semya-kak-sposob-ustroystva-deteyostavshihsya-bez-popecheniya-roditeley-v-soedinennyh-shtatah-ameriki. [in Russian]

5. Jantz A., Green R., Bess R., Andrews C. \& Russell V. (2002). The Continuing Evolution of State Kinship Care Policies. Washington, D. C.: The Urban Institute. [in English].

6. Geen R. Kinship Care: Making the Most of a Valuable Resource. Washington, DC: Urban Institute Press, 2003. [in English]. 